\title{
The Examination of Factors Relating to the Leadership Style of Nursing Leaders in Hospitals
}

\author{
Mateja Lorber \\ Faculty of Health Sciences, University of Maribor, Slovenia \\ mateja.lorber@um.si
}

\section{Sonja Treven}

Faculty of Economics and Business, University of Maribor, Slovenia

sonja.treven@um.si

\section{Damijan Mumel}

Faculty of Economics and Business, University of Maribor, Slovenia

damijan.mumel@um.si

\begin{abstract}
Theories often describe leadership with different classifications, based on personality and behaviour, and have been used to establish the traits and behaviours that determine an effective leadership style. We used the quantitative methodology to investigate the determinants of the leadership style among nursing leaders in Slovene hospitals. Based on the results, we determined that demographic characteristics such as gender, age, length of employment, and level of education do not affect the choice of the leadership style. Internal organizational characteristics such as job position, emotional intelligence, communication, personal characteristics, and the decision-making process are positively associated with the leadership style. Personal characteristics are considered important when it comes to using specific leadership styles, regardless of the choice of the leadership style, which also depends on the situation and external influences.
\end{abstract}

Key words: decision-making process, personal characteristics, communication, emotional intelligence, leadership style

\section{Introduction}

The importance of effective leadership in health care has been emphasized by a number of authors (Carney, 2006; Greenfield, 2007; Hewison, \& Griffiths, 2004; Sutherland \& Dodd, 2008), and nursing leadership is pivotal because nurses represent the most extensive discipline in health care (Marquis \& Huston, 2009; Oliver, 2006; Roussel, Swansburg, \& Swansburg, 2009; Sullivan \& Garland, 2010). Lombardi and Schemerhorn (2007) stated that a leader can be anyone in the organization who supports and is responsible for the work performance of one or more persons. Later, Huber (2013) noted that the leadership is defined as the process of working with individuals, groups, and other resources in order to achieve the objectives of the organization.

ORIGINAL SCIENTIFIC PAPER

RECEIVED: JULY 2015

REVISED: DECEMBER 2015

ACCEPTED: DECEMBER 2015

DOI: 10.1515/ngoe-2016-0003

UDK: 005.32:614.2

JEL: I10, M54, M12

Citation: Lorber, M., Treven, S., \& Mumel, D. (2016). The Examination of Factors Relating to the Leadership Style of Nursing Leaders in Hospitals. Naše gospodarstvo/Our Economy, 62(1), 27-36 DOI: 10.1515/ngoe-2016-0003

\section{NG OE}

NAŠE GOSPODARSTVO OUR ECONOMY

Vol. 62 No.1 2016

pp. $27-36$ 
In recent years, many theories and styles of leadership have been developed. Various styles of leadership demonstrate how to lead nurses in hospitals (Huber, 2006). Goethals, Sorenson, and Burns (2004) noted that transactional leadership was founded on the theory that employees are motivated by rewards and discipline. The transformational leadership styles focus on team-building, motivation, and collaboration with employees at different levels of the organization to accomplish change for the better. Leaders focus on encouraging all of the staff to set a good example and portray an optimistic personality. This style of leadership is based on the premise that employees are motivated to perform their job through the positive rather than negative incentives. Both types of the leadership style have benefits and drawbacks (Goethals et al., 2004; Marquis \& Huston, 2009). The laissez-faire leadership style is one style in which the leader provides little or no direction or supervision and prefers to take decisions alone. The changes occur rarely, and the quality improvement is typically low. This leadership style is most often used by new and inexperienced leaders or by those at the end of their career (Goethals et al., 2004; Skogstad, Einarsen, Torsheim, Aasland, \& Hetland, 2007).

The leadership style is a construct associated with the number of employees and organizational variables. A few of the verified connections are discussed here. The leadership style associated with the personality (Brown \& Reilly, 2009), organizational commitment (Avolio, Gardner, Walumbwa, Luthans, \& May, 2004; Geijsel, Sleegus, Lithwood, \& Jantzi, 2003; Leach, 2005), emotional intelligence (Barling, Kelloway, \& Slater, 2000; Downey, Papageorgiou, \& Stough, 2006; Vrba, 2007), organizational learning and adaptation (Castiglione, 2006), stress and burnout (Gill, Flaschner, \& Shacha, 2006; Kanste, Kyngas, \& Nikkila, 2007; Zopiatis \& Constanti, 2010), job satisfaction (Failla, \& Stichler, 2008; Mancheno-Smoak, Endres, Potak, \& Athanasaw, 2009; Sellgren, Ekvall, \&Tomson, 2008; Wu, 2009), work performance (Kozak \& Uca, 2008; MacKenzie, Podsakof, \& Rich, 2001; Vigoda-Gadot, 2007), motivating employees (Mehta, 2000) organizational culture (Bass \& Avolio, 1994; Kozak \& Uca, 2008; Sellgren et al., 2008), and well-being (Kuoppala, Lamminpää, Liira, \& Vainio, 2008; Nielsen, Yarker, Randall, \& Munir, 2008; Skakon, Nielsen, Borg, \& Guzman, 2010). Kouzes and Posner (1997) found that there is no the best leadership style; rather, leaders must choose the way of leading depending on the situation and circumstances. Effective leadership can encourage employees to take tasks, effectively solve problems, and make decisions that improve the efficiency of the team and the entire organization (Bennett, 2009).

Nursing leaders currently face many challenges (new roles, new technology, financial constraints, greater emphasis on participation, cultural diversity, and education). In every health care institution, the leadership must act to encourage effecting changes and achieving high standards of the patient care (Sullivan \& Garland, 2010). Heller and colleagues (2004) noted that nurses are not adequately prepared for the role of the leader during their nursing education programmes. Because of the importance of the leadership in nursing, we wanted to determine which leadership style is most frequently used by the nursing leaders in Slovene hospitals and which factors are associated with the leadership style.

\section{Methods}

The study used quantitative methodology. The data were collected in a cross-sectional survey among the employees in nursing in Slovene hospitals using an anonymous structured questionnaire.

\subsection{Instruments}

In the study, we used two questionnaires: one for the leaders and another for other employees in nursing. Leaders at the execution level of management, which act directly on the department or unit, participated in the study. Their emphasis is on the management and leadership of the unit, department, or team and the scope of the operation control, including the efficient provision of services, achieving better quality of care and patient satisfaction. It is important to recognize that the success of the organization depends on the success of individual units or departments of the organization. The questionnaires contained 50 closed-type questions that covered demographic data (gender, age, job position, years of employment, years of employment in a leading position, and the level of education) and, in the second part, 21 items for the leadership style, 10 characteristics of successful leaders, 6 items for the emotional intelligence, 7 items for the decision-making process, and 10 for the communication. Job position was used to describe a specific group of performed tasks (professional leader of department, team leader, nurses with diploma degree, nursing assistant). For the leadership style, we used the Multifactorial Leadership Questionnaire (Bass \& Avolio, 1994), which contains 12 items for the transformational leadership (Cronbach's alpha = 0.960), 6 items for the transactional leadership (Cronbach's alpha $=0.937$ ), and 3 items for the laissez-faire leadership style (Cronbach's alpha $=0.977)$. For communication, we used 10 items prepared in cooperation with O.K. Consulting (an education and transformational management company) and based on a theoretical background (Marquis \& Huston, 2009; Zidar Gale, 2004). The Cronbach's alpha was 0.977. For the decision-making process, we used 7 items prepared in 
cooperation with O.K. Consulting and based on a theoretical background (Dickson, Den Hartog, \& Mitchelson, 2003; Skela Savič, 2002). The Cronbach's alpha was 0.958. For emotional intelligence, we used 6 items prepared in the cooperation with O.K. Consulting and based on a theoretical background (Goleman, 2001; Goleman \& Boyatzis, 2008). The Cronbach's alpha was 0.974 . For personal characteristics, we used 10 characteristics of successful leaders (decisiveness, communicativeness, honesty, self-confidence, reliability, responsibility, objectivity, cooperation, organizing, ambitious). The Cronbach's alpha was 0.943. The leaders self-assessed their leadership style, personal characteristics, emotional intelligence, communication, and decision-making process using a 6-point Likert scale ranging from 1 (strongly disagree) to 6 (strongly agree). The employees assessed the leadership style, personal characteristics, emotional intelligence, communication and decision making of their direct leader on a 6-point Likert scale ranging from 1 (strongly disagree) to 6 (strongly agree). The questionnaires were tested in a pilot study (10 leaders and 40 employees).

\subsection{Sample}

In the current study, 8 of the 12 Slovene hospitals with internal medicine and surgery departments were included. We asked all 12 hospitals to participate, but four refused. The questionnaires were distributed to the morning shift by the author and the research coordinator in the participating hospitals. The nursing leaders were not selected randomly. The questionnaire was sent only to those with the job position relevant to the research, which means that purposive sampling was used. We distributed 1100 (85 to leaders and 1015 to other employees in nursing) questionnaires; 640 questionnaires were correctly and comprehensively filled out (response rate $=56 \%$ ).

The study included 640 employees in nursing from Slovene hospitals, of which 75 (12\%) were nursing leaders and 565 (88\%) were other employees in nursing. Participants included 87 (14\%) men and 553 (86\%) women. There were 346 (54\%) employees from the surgery department and 294 (46\%) employees from the internal medicine department. Of the participating employees, 24\% were younger than 30 years old, $64 \%$ were between 30 and 50 years of age, and 12\% were older than 50 years old. On average, the leaders had been in a leadership position for 8.6 years (from 0.5 to 32 years).

\subsection{Data Analysis}

We received written permission for the study from all participating hospitals and the National Medical Ethics Committee of the Republic of Slovenia (No.157/09/13). Before the research, we informed the respondents about the aim of the study, and participation in the study was voluntary and anonymous. The questionnaire took approximately 20 minutes to complete, and the study was conducted in the year 2014 (from April to September 2014).

For the statistical analysis, SPSS version 20.0 (IBM; SPSS Inc., Chicago, IL, USA) was used. The differences between individual variables were analysed using the Mann-Whitney test, while the Spearman correlation coefficient was used to identify the relationship between the studied variables. The linear regression analysis was used to determine the impact of gender, age, level of education, personal characteristics, communication, decision-making process, and emotional intelligence (independent variables) on the leadership style (dependent variable). A $p$-value of less than 0.05 was considered to be statistically significant.

\section{Results}

Table 1 shows that the leaders in nursing indicated that the most widely used leadership style is transactional $(\overline{\mathrm{x}}=4.22, s=0.72)$; however, their employees assessed that their leaders most often use the laissez-faire leadership style $(\overline{\mathrm{x}}=3.83, s=1.327)$. Significant differences occurred between the leaders' and other employees' perceptions of only the transactional leadership styles $(Z=-2.736$; $p=0.006)$. Table 1 highlights significant differences in the assessment of the leaders' communication $(Z=-3.377$; $p=0.001)$, leaders' emotional intelligence $(Z=-3.544$; $p<0.001)$, decision-making process $(Z=-3.963 ; p<0.001)$, and leaders' personal characteristics $(\mathrm{Z}=-5.823$; $p<0.001)$.

The Spearman correlation analysis (Table 2) showed a strong positive correlation between the leadership style and the leaders' communication, decision-making process, leaders' emotional intelligence, and leaders' personal characteristics.

In order to establish the factors' impact on transformational, transactional, and laissez-faire leadership styles, a regression analysis was conducted. For independent variables, we used gender, age, years of employment, level of education, job position, leaders' decision-making, leaders' emotional intelligence, leaders' communication, and leaders' personal characteristics. Because we intended to build the regression model, the residuals were tested for normality. The results of the Shapiro-Wilk indicated that, for the first regression model ( $\mathrm{df}=474 ; p=0.008$ ), the values of the residuals were not normally distributed. Despite the fact that residuals were not normally distributed, we built the first regression model. This represents a limitation of the research. We take this into account when presenting the results of this model. When we 
Table 1. Results of the Mann-Whitney Test

\begin{tabular}{lllllll} 
Variables & $\overline{\mathrm{x}}(\mathrm{L})$ & $\mathrm{s}(\mathrm{L})$ & $\overline{\mathrm{x}}(\mathrm{E})$ & $\mathrm{s}(\mathrm{E})$ & $\mathrm{Z}$ & $p$ \\
\hline Transformational leadership & 4.16 & 0.755 & 3.72 & 1.407 & -1.928 & 0.054 \\
\hline Transactional leadership & 4.22 & 0.711 & 3.56 & 1.407 & -2.736 & 0.006 \\
\hline Laissez-faire leadership & 4.04 & 0.748 & 3.83 & 1.327 & -0.879 & 0.379 \\
\hline Leaders' communication & 4.40 & 0.907 & 3.37 & 1.723 & -3.377 & 0.001 \\
\hline Leaders' emotional intelligence & 4.50 & 0.843 & 3.28 & 1.874 & -3.544 & $<0.001$ \\
\hline Leaders' decision-making process & 4.33 & 0.943 & 3.16 & 1.800 & -3.963 & $<0.001$ \\
\hline Leaders' characteristics & 5.42 & 0.827 & 4.21 & 1.396 & -5.823 & $<0.001$ \\
\hline
\end{tabular}

Note: $\mathrm{L}=$ leaders; $\mathrm{E}=$ other employees; $\overline{\mathrm{x}}=$ average; $\mathrm{s}=$ standard deviation; $\mathrm{Z}=$ value of Mann-Whitney test; $p=$ statistically significant at 0.05 or less

Table 2. Results of the Spearman Correlations for the Studied Variables

\begin{tabular}{lccccccc} 
& $\mathrm{TL}$ & $\mathrm{TS}$ & $\mathrm{LF}$ & $\mathrm{CO}$ & $\mathrm{DM}$ & $\mathrm{EI}$ & $\mathrm{PC}$ \\
\hline $\mathrm{TL}$ & 1 & $0.860^{* *}$ & $0.685^{* *}$ & $0.794^{* *}$ & $0.783^{* *}$ & $0.837^{* *}$ & $0.733^{* *}$ \\
\hline$p$ & $/$ & $<0.001$ & $<0.001$ & $<0.001$ & $<0.001$ & $<0.001$ & $<0.001$ \\
\hline $\mathrm{TS}$ & $0.860^{* *}$ & 1 & $0.720^{* *}$ & $0.801^{* *}$ & $0.797^{* *}$ & $0.861^{* *}$ & $0.726^{* *}$ \\
\hline$p$ & $<0.001$ & $/$ & $<0.001$ & $<0.001$ & $<0.001$ & $<0.001$ & $<0.001$ \\
\hline $\mathrm{LF}$ & $0.685^{* *}$ & $0.720^{* *}$ & 1 & $0.642^{* *}$ & $0.644^{* *}$ & $0.637^{* *}$ & $0.498^{* *}$ \\
\hline$p$ & $<0.001$ & $<0.001$ & $/$ & $<0.001$ & $<0.001$ & $<0.001$ & $<0.001$ \\
\hline $\mathrm{CO}$ & $0.794^{* *}$ & $0.801^{* *}$ & $0.642^{* *}$ & 1 & $0.842^{* *}$ & $0.882^{* *}$ & $0.744^{* *}$ \\
\hline$p$ & $<0.001$ & $<0.001$ & $<0.001$ & $/$ & $<0.001$ & $<0.001$ & $<0.001$ \\
\hline $\mathrm{DM}$ & $0.783^{* *}$ & $0.797^{* *}$ & $0.644^{* *}$ & $0.842^{* *}$ & 1 & $0.839^{* *}$ & $0.720^{* *}$ \\
\hline $\mathrm{EI}$ & $<0.001$ & $<0.001$ & $<0.001$ & $<0.001$ & $/$ & $<0.001$ & $<0.001$ \\
\hline$p$ & $0.837^{* *}$ & $0.861^{* *}$ & $0.637^{* *}$ & $0.882^{* *}$ & $0.839^{* *}$ & 1 & $0.775^{* *}$ \\
\hline $\mathrm{PC}$ & $<0.001$ & $<0.001$ & $<0.001$ & $<0.001$ & $<0.001$ & $/$ & $<0.001$ \\
\hline$p$ & $0.733^{* *}$ & $0.726^{* *}$ & $0.498^{* *}$ & $0.744^{* *}$ & $0.720^{* *}$ & $0.775^{* *}$ & 1 \\
\hline
\end{tabular}

Note: $\mathrm{TL}=$ transformational leadership; $\mathrm{TS}=$ transactional leadership; $\mathrm{LF}=$ laissez-faire leadership; $\mathrm{CO}=$ communication; $\mathrm{DM}=$ decision making; EI = emotional intelligence; $\mathrm{PC}=$ personal characteristics

tested the assumptions for the presented regression model, we excluded the problem of autocorrelation, multicollinearity, and heteroscedasticity. The results of these assumptions are presented below.

When we tested residuals for normality for the second ( $\mathrm{df}=20 ; p=0.316)$ and the third ( $\mathrm{df}=72 ; p=0.941$ ) regression models, we found that the values of the residuals are normally distributed. We also checked the assumption of autocorrelation, multicollinearity, and heteroscedasticity for the second and the third regression models. To verify autocorrelation, we used the Durbin-Watson test, which returned values of 1.721, 1.656, and 1.621 for the first, second, and third regression models, respectively. The Durbin-Watson statistics for all three regression models are within the acceptable range (i.e., from 1.50 to 2.50). The values of the
Durbin-Watson test show slightly positive, but acceptable correlations. Tables 3, 4, and 5 indicated that all the values of VIF factors are less than 10 and all values of the tolerance factors are higher than 0.2 . Therefore, we can conclude that our models did not present a problem of multicollinearity. We also checked the problem of heteroscedasticity using the Breusch-Pagan test, which is a hypothesis test of whether the pattern of the residuals is consistent across the range of predicted values. The results from all three models (first: $\mathrm{F}=1.630 ; p=0.125$; second: $\mathrm{F}=1.741 ; p=0.251$; third: $\mathrm{F}=0.598 ; p=0.440$ ) showed that heteroscedasticity is not a problem in this study.

The regression analysis demonstrated that job position ( $\beta=0.103 ; p<0.001)$, nursing leaders' decision-making process $(\beta=0.173 ; p=0.018$ ), leaders' communication 
Table 3. Results of the Regression Analysis for the Transformational Leadership Style

\begin{tabular}{lcccccccc} 
& $\mathrm{B}$ & $\mathrm{SE}$ & $\beta$ & $\mathrm{t}$ & $p$ & PART & TOL & VIF \\
\hline Gender & 0.013 & 0.031 & 0.009 & 0.420 & 0.675 & 0.062 & 0.929 & 1.076 \\
\hline Age & 0.001 & 0.003 & 0.014 & 0.263 & 0.793 & 0.031 & 0.605 & 1.654 \\
\hline Years of Employment & 0.001 & 0.003 & 0.020 & 0.373 & 0.709 & 0.023 & 0.633 & 1.580 \\
\hline Level of education & 0.009 & 0.010 & 0.021 & 0.918 & 0.354 & 0.008 & 0.828 & 1.207 \\
\hline Job position & 0.160 & 0.034 & 0.103 & 4.681 & $<0.001$ & 0.195 & 0.772 & 1.295 \\
\hline Leaders' communication & 0.223 & 0.050 & 0.223 & 4.424 & $<0.001$ & 0.266 & 0.137 & 7.301 \\
\hline Leaders' decision-making & 0.173 & 0.045 & 0.173 & 2.365 & 0.018 & 0.331 & 0.143 & 7.004 \\
\hline Leaders' emotional intelligence & 0.500 & 0.047 & 0.501 & 7.975 & $<0.001$ & 0.681 & 0.246 & 4.086 \\
\hline Leaders' personal characteristics & 0.079 & 0.013 & 0.220 & 5.938 & $<0.001$ & 0.018 & 0.240 & 4.168 \\
\hline
\end{tabular}

Note: $\mathrm{B}=$ unstandardized coefficient; $\mathrm{SE}=$ standard error; $\beta=$ standardized regression coefficient; $\mathrm{t}=\mathrm{t}$-test value; $p=$ statistically significant at 0.05 or less; PART = partial correlations; TOL = tolerance; VIF = variance inflation factor

Table 4. Results of the Regression Analysis for the Transactional Leadership Style

\begin{tabular}{lcccccccc} 
& $\mathrm{B}$ & $\mathrm{SE}$ & $\beta$ & $\mathrm{t}$ & $p$ & $\mathrm{PART}$ & TOL & VIF \\
\hline Gender & 0.012 & 0.029 & 0.009 & 0.426 & 0.670 & 0.083 & 0.923 & 1.084 \\
\hline Age & 0.003 & 0.03 & 0.051 & 1.011 & 0.312 & 0.081 & 0.615 & 1.623 \\
\hline Years of Employment & 0.001 & 0.002 & 0.016 & 0.321 & 0.749 & 0.031 & 0.644 & 1.553 \\
\hline Level of education & 0.004 & 0.009 & 0.008 & 0.403 & 0.687 & 0.049 & 0.837 & 1.194 \\
\hline Job position & 0.002 & 0.033 & 0.001 & 0.049 & 0.961 & 0.146 & 0.772 & 1.295 \\
\hline Leaders' communication & 0.242 & 0.045 & 0.241 & 5.318 & $<0.001$ & 0.169 & 0.136 & 7.377 \\
\hline Leaders' decision-making & 0.116 & 0.041 & 0.116 & 2.470 & 0.014 & 0.397 & 0.143 & 7.013 \\
\hline Leaders' emotional intelligence & 0.502 & 0.044 & 0.501 & 9.358 & $<0.001$ & 0.669 & 0.242 & 4.137 \\
\hline Leaders' personal characteristics & 0.062 & 0.012 & 0.175 & 5.121 & 0.021 & 0.034 & 0.233 & 4.285 \\
\hline
\end{tabular}

Note: $\mathrm{B}=$ unstandardized coefficient; $\mathrm{SE}=$ standard error; $\beta=$ standardized regression coefficient; $\mathrm{t}=\mathrm{t}$-test value; $p=$ statistically significant at 0.05 or less; PART = partial correlations; TOL = tolerance; VIF = variance inflation factor

Table 5. Results of the Regression Analysis for the Laissez-faire Leadership Style

\begin{tabular}{lcccccccc} 
& $\mathrm{B}$ & $\mathrm{SE}$ & $\beta$ & $\mathrm{t}$ & $p$ & $\mathrm{PART}$ & TOL & VIF \\
\hline Gender & 0.008 & 0.082 & 0.003 & 0.099 & 0.921 & 0.049 & 0.952 & 1.050 \\
\hline Age & 0.004 & 0.008 & 0.039 & 0.540 & 0.590 & 0.041 & 0.615 & 1.626 \\
\hline Years of Employment & 0.001 & 0.007 & 0.009 & 0.117 & 0.907 & 0.088 & 0.933 & 1.071 \\
\hline Level of education & 0.012 & 0.029 & 0.014 & 0.406 & 0.585 & 0.023 & 0.849 & 1.178 \\
\hline Job position & 0.066 & 0.092 & 0.021 & 0.713 & 0.476 & 0.128 & 0.792 & 1.262 \\
\hline Leaders' communication & 0.228 & 0.144 & 0.116 & 1.582 & 0.114 & 0.121 & 0.134 & 7.478 \\
\hline Leaders' decision-making & 0.756 & 0.120 & 0.385 & 6.318 & $<0.001$. & 0.395 & 0.137 & 7.308 \\
\hline Leaders' emotional intelligence & 0.488 & 0.145 & 0.248 & 3.365 & 0.001 & 0.576 & 0.222 & 4.507 \\
\hline Leaders' personal characteristics & 0.029 & 0.038 & 0.041 & 0.760 & 0.448 & 0.068 & 0.220 & 4.540 \\
\hline
\end{tabular}

Note: $\mathrm{B}=$ unstandardized coefficient; $\mathrm{SE}=$ standard error; $\beta=$ standardized regression coefficient; $\mathrm{t}=\mathrm{t}$-test value; $p=$ statistically significant at 0.05 or less; PART = partial correlations; TOL = tolerance; VIF = variance inflation factor 
( $\beta=0.223 ; p<0.001)$, leaders' emotional intelligence $(\beta=0.501 ; p<0.001)$, and leaders' personal characteristics $(\beta=0.220 ; p<0.001)$ impacted the use of the transformational leadership style. The regression analysis can explain $78 \%$ of the total variability of the transformational leadership style with the studied independent variables.

The regression analysis also showed that leaders' communication ( $\beta=0.241 ; p<0.001$ ), leaders' decision-making process $(\beta=0.166$; $p=0.014)$, leaders' emotional intelligence $(\beta=0.501 ; p<0.001)$, and leaders' personal characteristics $(\beta=0.175 ; p<0.021)$ affected the use of the transactional leadership style. The regression analysis explained $73 \%$ of the total variability of the transactional leadership style with the studied independent variables.

The regression analysis also showed that the decision-making process $(\beta=0.385 ; p<0.001)$ and leaders' emotional intelligence ( $\beta=0.248 ; p=0.248$ ) impacted the use of the laissez-faire leadership style. The regression analysis explained $62 \%$ of the total variability of the laissez-faire leadership style with the studied independent variables.

\section{Discussion and Conclusion}

We found that the leaders most widely use the transactional leadership style. We also identified statistically significant differences in the assessment of the transactional leadership style between leaders and other employees in nursing. Kleinman (2004) found that nursing leaders consistently perceived that they used the transformational leadership style compared to the perceptions among their staff. Kleinman (2004) also found that nursing leaders and other nurses do not agree about the frequency of use the transformational leadership style; however, they do agree about the frequency of use the transactional leadership style. In addition, Hendel, Fish, and Galon (2005) found that the nursing leaders perceive themselves as transformational leaders much more often than as transactional leaders. Hospitals and other health care institutions, by nature, tend to be bureaucratic organizations in which the transformational leadership may not be fostered to the greatest possible degree. Ramey (2002) noted that a contingent reward is a feature of the transformational leadership style for nurses.

In the research, the employees in nursing perceived their leaders as mostly using the laissez-faire leadership style. Findings from previous studies indicate that the laissez-faire leadership style is the least effective form of leaders' behaviour (Khan, Ramzan, Ahmed, \& Nawaz, 2011) and is likely to have a negative relationship with job satisfaction (Rowold \& Wolff, 2009). Skogstad and colleagues (2007) found that the laissez-faire leadership style is positively correlated with role conflict, role ambiguity, and conflicts with co-workers. They further noted that their results support the assumption that the laissez-faire leadership is a destructive leadership behaviour. As we found in our research, nursing leaders continue to use the transactional and laissez-faire styles, which may be causing nurses to leave the profession. In contrast to the transactional leadership style, the transformational leadership style and team development have a positive effect on communication and team building. We further identified that transformational, transactional, and laissez-faire leadership styles have a positive correlation, and we agree with previous research (DuBrin, 2004; Goleman, 2001; Northouse, 2001; Scott, Bishop, \& Chen, 2003) that noted that effective leaders conduct their work using different styles of leadership and successfully adapt to co-workers, situations, and the environment in which they work.

The research demonstrated that, for leadership styles, leaders' communication, emotional intelligence, decision-making, and personal characteristics are important. Nursing leaders set an example-either positive or negative-for others. AANAC (2013) noted that, regardless of the leadership activity, it is important for leaders to act with integrity, set realistic goals, communicate clearly, encourage others, recognize the successes of team members, and inspire them to provide the best patient care.

Emotional intelligence is an important quality of leaders in nursing and also has an impact on leadership styles. We agree with previous researchers (Chiva \& Alegre, 2008; Clarke, 2010; Kafetsios \& Zampetakis, 2008; Kerr, Garvin, Heaton, \& Boyle, 2006; Mittal \& Sindhu, 2012; Naidu, 2014), who found that - for the leaders' success - it is essential to have a high degree of emotional intelligence. Another important factor is the leaders' communication. In order to maintain good interpersonal relationships, the leaders should master a variety of communication skills and have the ability to understand the needs of others. Some studies (Fix \& Sias, 2006; Kim, 2002; Madlock, 2008; Mueller \& Lee, 2002) have found that leaders' communication is a strong predictor of employees' satisfaction. According to some researchers (Lorber \& Skela Savič, 2011; Skela Savič, 2007; Yazbeck, 2004), hierarchy and leaders' power represent the biggest problem of effective communication in a hospital. But Zidar Gale (2004) noted that leaders with well-developed communication skills contribute to greater productivity and employees' satisfaction.

Another factor determining the leadership style that cannot be ignored is the personality of an individual who leads a group of employees. We found that leaders' personal characteristics have an impact on leadership styles. Leaders' behaviour affects employees. According to previous research 
(Cimerman, Jerman, Klarič, Ložar, \& Sušanj, 2003; DuBrin, 2004; Holden Leadership Center, 2009; Mayer, 2003), leaders' personal characteristics are important for successful leadership.

Leaders' behaviour is reflected through their employees in the care they give to their patients each day, regardless of the leadership style used. The leaders must recognize the importance of their role and that younger employees rely on their leadership in developing their own professional skills. Leaders must also use behaviour to positively influence organizational outcomes and must appreciate the interconnectedness among developing nursing practice, improving quality of care, and optimizing patient outcomes. Health care organizations need nursing leaders who can improve nursing care, are an advocate for the nursing profession, and have a positive effect on health care.
This study has some limitations. The research framework was based on the theoretical findings discussing leadership style, communication, emotional intelligence, and decision-making process, so we only studied the influence of some predictors on a leadership style. Because some questionnaires were sent by mail and a researcher was not available in all participating hospitals, the respondents did not get any help if they did not understand the items. Another limitation of the study is that residuals were not normally distributed for one of the created regression models.

The studied topic provides opportunities for further research. It could be conducted in all health care institutions in Slovenia. Our results emphasize the possible contribution and utility of programs especially designed to improve communication skills, emotional intelligence, and decision-making skills among leaders and other employees in nursing.

\section{References}

1. AANAC. (2013). Nursing leadership: Management and leadership styles. Retrieved from https://www.aanac.org/docs/white-papers/2013-nursing-leadership---management-leadership-styles.pdf?sfvrsn=4

2. Avolio, B. J., Gardner, W. L., Walumbwa, F. O., Luthans, F., \& May, D. R. (2004). Unlocking the mask: A look at the process by which authentic leaders impact follower attitudes and behaviors. Leadership Quarterly, 15, 801-823. http://dx.doi.org/10.1016/j. leaqua.2004.09.003

3. Barling, J., Kelloway, E. K., \& Slater, F. (2000). TL and emotional intelligence: An exploratory study. Leadership and Organization Development Journal, 21(3), 157-161. http://dx.doi.org/10.1108/01437730010325040

4. Bass, B., \& Avolio, B. (1994). Developing transformational leadership: 1992 and beyond. Journal of European Industrial Training, 14(5), 21-27.

5. Bennett, T. (2009). The relationship between the subordinate's perception of the leadership style of its managers and the subordinate's perceptions of manager's ability to inspire extra effort, to be effective, and to enhance satisfaction with management. Proceedings of the Academy of Strategic Management, 8(1), 11.

6. Brown, F. W., \& Reilly, M. D. (2009). The Myers-Briggs type indicator and transformational leadership. Journal of Management Development, 28(10), 916-932. http://dx.doi.org/10.1108/02621710911000677

7. Carney, M. (2006). Health service management: Consensus, culture and the middle manager. Cork: Oak Tree Press.

8. Castiglione, J. (2006). Organizational learning and transformational leadership in the library environment. Library Management, 27(4/5), 289-299. http://dx.doi.org/10.1108/01435120610668223

9. Chiva, R., \& Alegre, J. (2008). Emotional intelligence and job satisfaction: the role of organizational learning capability. Personnel Review, 37(6), 680-701. http://dx.doi.org/10.1108/00483480810906900

10. Cimerman, M., Jerman, S., Klarič, R., Ložar, B., \& Sušanj, Z. (2003). Manager prvi med enakimi. Ljubljana: GV Založba.

11. Clarke, N. (2010). Emotional intelligence and its relationship to transformational leadership and key project manager competences. Project Management Journal, 41(2), 5-20. http://dx.doi.org/10.1002/pmj.20162

12. Downey, L. A., Papageorgiou, V., \& Stough, C. (2006). Examining the relationship between leadership, emotional intelligence and intuition in senior female managers. Leadership and Organization Development Journal, 27(4), 250-264. http://dx.doi. org/10.1108/01437730610666019

13. Dickson, M.W., Den Hartog, D. N., \& Mitchelson,J. K. (2003). Research on leadership in a cross-cultural context: Making progress and raising new questions. The Leadership Quaterly, 14(6), 729-768. http://dx.doi.org/10.1016/j.leaqua.2003.09.002

14. DuBrin, A. J. (2004). Leadership. Boston: Houghton Mifflin Company.

15. Failla, K. R., \& Stichler,J. F. (2008). Manager and staff perceptions of the manager's leadership style.Journal of Nursing Administration, 38(11), 480-487. http://dx.doi.org/10.1097/01.NNA.0000339472.19725.31

16. Fix, B., \& Sias, P. M. (2006). Person-centered communication, leader-member exchange, and employee job satisfaction. Communication Research Reports, 23(1), 35-44. http://dx.doi.org/10.1080/17464090500535855

17. Geijsel, F., Sleegus, P., Lithwood, K., \& Jantzi, D. (2003). Transformational leadership effect on teachers' commitment and effort towards school reform. Journal of Educational Administration, 41, 228-256. http://dx.doi.org/10.1108/09578230310474403

18. Gill, A. S., Flaschner, A. B., \& Shacha, M. (2006). Mitigating stress and burnout by implementing transformational leadership. International Journal of Contemporary Hospitality Management, 18(6), 469-481. http://dx.doi.org/10.1108/09596110610681511 
19. Goethals, G., Sorenson, G., \& Burns, J. (2004). Encyclopedia of leadership. Thousand Oaks, CA: SAGE Publications. http://dx.doi. org/10.4135/9781412952392

20. Goleman, D (2001). Emotional intelligence: Issues in paradigm building. In C. Cherniss \& D. Goleman (Eds.), The emotionally intelligent workplace (pp. 13-26). Jossey-Bass: San Francisco.

21. Goleman, D., \& Boyatzis, R. (2008). Social intelligence and the biology of leadership. Harvard Business Review. Retrieved from http:// hbr.org/2008/09/social-intelligence-and-the-biology-of-leadership/ar/1

22. Greenfield, D. (2007). The enactment of dynamic leadership. Leadership in Health Services, 20(3), 159-168. http://dx.doi. org/10.1108/17511870710764014

23. Heller, B. R., Drenkard, K., Esposito-Herr, M. B., Romano, C., Tom, S., \& Valentine, N. (2004). Educating nurses for leadership roles. Journal of Continuing Education in Nursing, 35(5), 203-210.

24. Hendel, T., Fish, M., \& Galon, V.(2005). Leadership style and choice of strategy in conflict management among Israeli nurse managers in general hospitals. Journal of Nursing Management, 13(2), 137-146. http://dx.doi.org/10.1111/j.1365-2934.2004.00525.x

25. Hewison, A., \& Griffiths, M. (2004). Leadership development in health care: a word of caution. Journal of Health Organization and Management, 18(6), 464-473. http://dx.doi.org/10.1108/14777260410570018

26. Holden Leadership Center. (2009). Leadership. Retrieved from University of Oregon at: http://leadership.uoregon.edu/

27. Huber, D. L. (2006). Leadership and nursing care management (3 $3^{\text {rd }}$ ed.). Philadelphia: Elsevier Inc.

28. Huber, D. L. (2013). Leadership \& nursing care management ( $5^{\text {th }}$ ed.). Retrieved from http://www.google.si/books?hl=sl\&lr=\&id=CZx5AAAAQBAJ\&oi=fnd \&pg=PP1\&dq=management+in+nursing \&ots=uYGNAI7JXb\&sig=g1sbD0QuiqVLNrzZkuVZZdb6zn0\&redir_es$\mathrm{c}=\mathrm{y} \# \mathrm{v}=$ onepage $\& \mathrm{q}=$ management $\% 20$ in $\% 20$ nursing $\& \mathrm{f}=\mathrm{false}$

29. Kafetsios, K., \& Zampetakis, L.A. (2007). Emotional intelligence and job satisfaction: Testing the mediatory role of positive and negative affect at work. Personality and Individual Differences, 44(3), 712-722. http://dx.doi.org/10.1016/j.paid.2007.10.004

30. Kanste, O., Kyngas, H., \& Nikkila, J. (2007). The relationship between multidimensional leadership and burnout among nursing staff. Journal of Nursing Management, 15, 731-739. http://dx.doi.org/10.1111/j.1365-2934.2006.00741.x

31. Kerr, R., Garvin, J., Heaton, N., \& Boyle, E. (2006). Emotional intelligence and leadership effectiveness. Leadership \& Organization Development Journal, 27(4), 265-279. http://dx.doi.org/10.1108/01437730610666028

32. Khan, M., Ramzan, M., Ahmed, I., \& Nawaz, M. (2011). Transformational, transactional, and laissez-faire styles of teaching faculty as predictors of satisfaction, and extra effort among the students: evidence from higher education institutions. Interdisciplinary Journal of Research in Business, 1(4), 130-135.

33. Kim, S. (2002). Participative management and job satisfaction: Lessons for management leadership. Public Administration Review, 62(2), 231-241. http://dx.doi.org/10.1111/0033-3352.00173

34. Kleinman, C. (2004). The relationship between managerial leadership behaviors and staff nurse retention. Hospital Topics, 82(4), $2-9$. http://dx.doi.org/10.3200/HTPS.82.4.2-9

35. Kouzes, J. M., \& Posner, B. Z. (1997). Leadership practices inventory-Industrial contributor (LPI-IC). Observer response sheet. San Francisco, CA: Jossey Bass/Pfeiffer.

36. Kozak, M., \& Uca, S. (2008). Effective factors in the constitution of leadership styles: a study of Turkish hotel managers. Anatolia-Ankara-International. Journal of Tourism and Hospitality Research, 19,117-130. http://dx.doi.org/10.1080/13032917.2008.9687057

37. Kuoppala, J., Lamminpää, A., Liira, J., \& Vainio, H. (2008). Leadership, job well-being, and health effects-A systematic review and a meta-analysis.Journal of Occupational \& Environmental Medicine, 50(8), 904-915. http://dx.doi.org/10.1097/J0M.0b013e31817e918d

38. Leach, L. S. (2005). Nurse executive transformational leadership and organizational commitment. The Journal of Nursing Administration, 35(5), 228-237. http://dx.doi.org/10.1097/00005110-200505000-00006

39. Lombardi, D. M., \& Schermerhorn, J. R. (2007). Healthcare management. Hoboken, NJ: John Wiley and Sons.

40. Lorber, M., \& Skela Savič, B. (2011). Komunikacija in reševanje konfliktov v zdravstveni negi. Obzornik zdravstvene nege, 45(4), 247-252

41. MacKenzie, S., Podsakof, P., \& Rich, G. (2001). Transformational and transactional leadership and salesperson performance. Journal of Academy of Marketing Science, 29(2), 115-125. http://dx.doi.org/10.1177/03079459994506

42. Madlock, P. E. (2008). The link between leadership style, communicator competence, and employee satisfaction. International Journal of Business Communication, 45(1), 61-78. http://dx.doi.org/10.1177/0021943607309351

43. Mancheno-Smoak, L., Endres, G., Potak, R., \& Athanasaw, Y. (2009). The individual cultural values and job satisfaction of the transformational leader. Organizational Development Journal, 27(3), 9-21.

44. Marquis, B. L., \& Huston, C. J. (2009). Leadership roles and management functions in nursing: Theory and application (6 $6^{\text {th }}$ ed.). Philadelphia: Wolters/Kluwer/Lippincott Williams and Wilkins.

45. Mayer, J. (2003). Lastnosti uspešnih vodij. Organizacija, revija za management, informatiko in kadre, 36(6), 368-376.

46. Mehta, R. (2000). Impact of leadership style on channel partner motivation. Journal of Marketing Channels, 7, 121-153. http://dx.doi. org/10.1300/J049v07n03_06

47. Mittal, E.V., \& Sindhu, E. (2012). Emotional intelligence \& leadership. Global Journal of Management and Business Research, 12(16), 34-37.

48. Mueller, H. B., \& Lee, J. (2002). Leader-member exchange and organizational communication satisfaction in multiple contexts. International Journal of Business Communication, 39(2), 220-244. http://dx.doi.org/10.1177/002194360203900204

49. Naidu, N. G. (2014). Emotional intelligence and leadership. International Journal of Entrepreneurship \& Business Environment Perspectives, 3(1). Retrieved from http://pezzottaitejournals.net/index.php/IJEBEP/article/view/1115 
50. Nielsen, K., Yarker, J., Randall, R., \& Munir, F. (2008). The mediating effects of team and self-efficacy on the relationship between transformational leadership, and job satisfaction and psychological well-being in healthcare professionals: A cross-sectional questionnaire survey. International Journal of Nursing Studies, 46(9), 1236-1244. http://dx.doi.org/10.1016/j.ijnurstu.2009.03.001

51. Northouse, P. G. (2001). Leadership. Thousand Oaks, CA, and London: Sage.

52. Oliver, S. (2006). Leadership in health care. Musculoskeletal Care, 4(1), 38-47. http://dx.doi.org/10.1002/msc.17

53. Ramey, J. (2002). The relationship between leadership styles of nurse managers and staff nurse job satisfaction in hospital settings. Retrieved from www.marshall.edu

54. Roussel, L., Swansburg, R. C., \& Swansburg, R. J. (2009). Management and leadership for nurse administrators (5 ${ }^{\text {th }}$ ed.).Sudbury , MA: Jones and Bartlett Publishers.

55. Rowold, J., \& Wolff, S. (2009). Transformational and transactional leadership and followers' chronic stress. Kravis Leadership Institute Leadership Review, 9, 35-48.

56. Scott, D., Bishop, J. W., \& Chen, X. (2003). An examination of the relationship of employee involvement with job satisfaction, employee cooperation, and intention to quit in US invsted enterprise in China. International Journal of Orgaizational Analysis, 11(1), 3-19. http://dx.doi.org/10.1108/eb028960

57. Sellgren, S. F., Ekvall, G., \& Tomson, G. (2008). Leadership behaviour of nurse managers in relation to job satisfaction and work climate. Journal of Nursing Management, 16(5), 578-587. http://dx.doi.org/10.1111/j.1365-2934.2007.00837.x

58. Skakon, J., Nielsen, K., Borg, V., \& Guzman, J. (2010). Are leaders' well-being, behaviours and style associated with the affective well-being of their employees? A systematic review of three decades of research. Work \& Stress: An International Journal of Work, Health \& Organisations, 24(2), 107-139. http://dx.doi.org/10.1080/02678373.2010.495262

59. Skela Savič, B. (2002). Dejavniki in kriteriji uspešnega vodenja v zdravstvu. Magistrsko delo. Kranj: Univerza v Mariboru, Fakulteta za organizacijske vede.

60. Skela Savič, B. (2007). Dejavniki uspešnega izvajanja sprememb v slovenskem zdravstvu. Doktorska disertacija. Kranj: Univerza v Mariboru, Fakulteta za organizacijske vede.

61. Skogstad, A., Einarsen, S., Torsheim, T., Aasland, M. S., \& Hetland, H. (2007). The destructiveness of laissez-faire leadership behavior. Journal of Occupational Health Psychology, 12(1), 80-92. http://dx.doi.org/10.1037/1076-8998.12.1.80

62. Sullivan, E. J., \& Garland, G. (2010). Practical leadership and management in nursing. Harlow: Pearson Education Limited.

63. Sutherland, A. M., \& Dodd, F. (2008). NHS Lanarkshire's leadership development programs impact on clinical practice. International Journal of Health Care Quality Assurance, 21(6), 569-584. http://dx.doi.org/10.1108/09526860810900727

64. Vigoda-Gadot, E. (2007). Leadership style, organizational politics and employees' performance: An empirical examination of two competing models. Personnel Review, 36, 661-983. http://dx.doi.org/10.1108/00483480710773981

65. Vrba, M. (2007). Emotional intelligence skills and leadership behavior in a sample of South Africa. Management Dynamics. Retrieved from https://www.questia.com/library/journal/1P3-1357960571/emotional-intelligence-skills-and-leadership-behaviour

66. Wu, F. (2009). The relationship between leadership styles and foreign English teachers job satisfaction in adult English cram schools: Evidence in Taiwan. The Journal of American Academy of Business, 14(2). Retrieved from http://www.jaabc.com/jaabcv14n2preview.html

67. Yazbeck, A. M. (2004). Introducing clinical pathways in the Slovene hospital (clinical) setting: Professional cultures and changes in organizational behavior. Magistrska naloga. Ljubljana: Univerza v Ljubljani, Ekonomska fakulteta.

68. Zidar Gale, T.(2004). Medosebno komuniciranje na delovnem mestu:z osebnimi spremembami do boljših medosebnih odnosov. Ljubljana: GV Izobraževanje.

69. Zopiatis, A., \& Constanti, P. (2010). Leadership styles and burnout: is there an association?. International Journal of Contemporary Hospitality Management, 22, 300-320. http://dx.doi.org/10.1108/09596111011035927

\section{Authors}

Mateja Lorber is a senior lecturer at the University of Maribor, Faculty Health Sciences. She is a Ph.D. student at the University of Maribor, Faculty of Economics and Business. Her main areas of interest and lecturing are leadership, nursing, research, and managing chronic diseases. She has presented her work at international scientific conferences and published original scientific papers in domestic and foreign scientific journals.

Sonja Treven, Ph.D., is a professor employed at the Faculty of Economics and Business at the University of Maribor in Slovenia, focusing in the field of human resource management and organizational behavior. She is the head of the Department of Management and Organization as well as the head of the Institute of Organization and Information Systems. She is the author/co-author of 13 books as well as more than 80 scientific articles. She has participated in more than 100 domestic and international conferences as an author or co-author of various papers. 
Damijan Mumel works as a professor of marketing at the University of Maribor, Faculty of Economics and Business. He is the head of the Marketing Institute and vice dean for research. His main areas of interest and lecturing are consumer behavior, research methodology, qualitative research, and communication. He has presented his work at international scientific conferences and published original scientific papers in domestic and foreign scientific journals. He is a member of the Slovenian Marketing Association and the Slovenian Psychologists' Association as well as the European Marketing Academy (EMAC).

\section{Proučevanje dejavnikov, ki se povezujejo s slogom vodenja vodij zdravstvene nege $v$ bolnišnicah}

\section{Izvleček}

V literaturi je zaslediti različne teorije vodenja na osnovi značilnosti in vedenja vodij. Uporabljajo se za določitev značilnosti, ki pripomorejo k uporabi učinkovitega sloga vodenja. V raziskavi smo uporabili kvantitativno metodologijo za proučitev dejavnikov sloga vodenja vodij zdravstvene nege v slovenskih bolnišnicah. Na podlagi rezultatov smo ugotovili, da demografske značilnosti, kot so spol, starost, leta zaposlitve in stopnja izobrazbe, ne vplivajo na izbiro sloga vodenja. S slogom vodenja se pozitivno povezujejo čustvena inteligenca, komunikacija, osebnostne značilnosti in proces odločanja. Za uporabo izbranega sloga vodenja so pomembne osebnostne značilnosti vodij, izbira sloga vodenja pa ja odvisna od situacije in zunanjih vplivov.

Ključne besede: proces odločanja, osebnostne značilnosti, komunikacija, čustvena inteligenca, slog vodenja 